山根常男著

\title{
『家族と社会 一社会生態学の理論を目ざして』
}

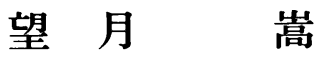

本書は、『家族と人格一家族の力動理論を目指して一』(1986)、『家族と結婚一脱家父長制の理論を目 指して一』（1990）に続く、山根の 3 作目の著書である。著者自身も述べているように、この 3 部作で、 いわゆる「山根家族論」の一応の完成をみることになる。山根といえば、キブツの研究者というイメー ジが強いが、そのキブツの研究を通して、人間にとって家族がいかに重要であるかを痛感して、家族研 究に入った。山根家族論は、家族を個人 ·家族・社会という横の文脈と、過去・現在・未来という縦の 文脈のなかに位置付け、これを全体的、力動的、発生的、歴史的に研究するという視点で展開される。 その理論的基礎には、フロイトの精神分析学があることを特徵とし、日本の家族社会学界に独自の地位 を築いた。本書は、I 家族の哲学、II 現代社会と家族、III 日本における家族の現状、N 家族の未来の 4 部から成る本論に加えて、駒沢大学退職記念最終講義「私の家族研究について」と戸田貞三著作集出版 祝賀会での講演「私の家族研究と戸田貞三先生」（筆者の記憶違いであればお許しいただきたい）が揭 載されている。さらに山根の「履歴と業績」もあり、文字通り山根家族論の集大成となっている。

「家族の哲学」では、性、文化、人間、歴史、家族といった多様な領域を扱いながら、家族をどうと らえるかという山根の基本的姿勢が展開される。ここでは、家族とは何かという定義づけはしていない が、「父母子の絆」を家族の原点としている。それは、家族を否定したといわれているキブツのなかに も観察されたものであり、山根の家族研究の原点でもある。父母子の絆は、一見「核家族」と同義にみ えるが、日本独自の用語である「核家族化」との関連で、核家族と短絡的に結びつけることを拒否して いる。核家族化は単なる形態上の概念ではなく、価值的な概念であるとし、それは個人主義原理に基づ く家父長的家制度へのアンチテーゼであるとしている。すなわち、山根は核家族の概念は日本国憲法第 24 条に示された個人の尊厳と両性の本質的平等を理念とする「近代家族」概念に近いものといえる。

ここで注目すべきことは、人間、家族、文化を「矛盾的存在」としていることである。人間存在その ものが性本能と攻撃本能をもつというフロイトの人間観を基礎として、文化の発達も正の効果だけでな く、負の効果をも合わせもつ。個人と家族、家族と社会もまた相互に矛盾する側面もあることを指摘す る。この矛盾を克服するためにこそエコロジカルなアプローチが必要であるということになる。

こうした立場から、「現代社会と家族」では、産業革命以後の社会の発展、すなわち社会の近代化が、 自然破壊と人間性破壊をもたらしていることを指摘し、それは人間が人類史上初めて遭遇した危機であ ると掲破する。そして、こうした状況から人間を救済する究極の責任は人間自身にあり、人類の未来に 対して、現在の人間に課せられた重要な課題であるという認識が示される。そのためには、どのような 人格形成をするかが問題であり、その重要な社会機関として家族と教育機関の在り方が問われることに なる。家族の基本的な機能として、教育機能をあげる山根家族論の意義もここにあるといえる。人間性 
とプライヴァシーのとりでとしての家族、社会への批判と抵抗の原点としての家族の重要性の指摘は、 安易な家族制度解体論にとって一つの警告となっている。

「日本における家族の現状」では、家族と夫婦、家族と職業、家族と教育、家族と老人の 4 側面から、 現在の日本の家族が抱える諸問題を具体的に論じている。現代の日本の家族は多くの問題点をもってい るが、だからといって、近代家族の終焉だとかパラダイムの転換が必要だということにはならない。む しろ、脱家父長制家族こそ課題であり、近代家族の理念の徹底こそ、日本の家族の当面する課題である と論じている。最後の「家族の未来」はその意味でも興味深い議論である。ここでは、まず現代家族の 結合の弛緩から説きおこし、現代では、家族以外の生活様式が容認されるようになっていることを指摘 する。しかし、それは今始まったことではなく昔からあったことを指摘している。そして、家族という 生活様式は「着古した外套」のようなもので、やがて他の生活様式にとって代わられる運命にあるとす るのは䛊りであると明言する。ついで、家族否定論として、ユートピア論とフェミニズム論をとりあげ る。フェミニズム論のうち家族否定につながるのは、シュラミット・ファイアストンに代表される過激 派であるとする。大胆に要約すれば、ユートピア論は家族と国家との関係で、理想国家の実現のために 家族結合が妨げになるという視点であるのに対して、フェミニズム論は家族と個人との関係で、家族は 個人を抑圧するという観点から、家族が否定されるという傾向があるということである。山根の指摘で 重要なことは、ユートピア論にしてもフェミニズム論にしても家族否定の対象とされる家族は、家父長 制家族であるというこである。したがって、「社会および個人の未来にとって必要不可欠な条件は、家 族をして家父長制から脱せしめることに他ならない」。家族は、人間が人間であることを否定する制度 ではなく、人間存在にとって必要不可欠な、人間存在のためにある制度なのである。

このような観点から、現在の日本の家族がなさねばならない基本的課題は、(1)家族の制度的重要性を 軽視する社会風潮に対して、「家族防衛」をすることであり、(2)性的、年齡的に上下関係を当然のこと とした家父長制を克服する「家族改革」であり、(3)家族がその責任を十分に果たすことができるような 社会的条件を整備する「家族政策」であり、(4)夫婦にとっては、社会生活を離れて私的生活を行なうフ ライヴァシーのとりでであり、子どもにとっては人間として成長する人間性のとりでである家庭機能の 重要性を認識する「家庭改造」であるという。こうして、家族は社会に適応するだけでなく、社会に対 して批判的存在であるというエコロジカルな性格をもっている。その意味では、いたずらに家族概念を 拡大して、家族以外の生活様式まで家族と称することは問題である。今問われるべきは、新しい家族の 存在ではなく、家族本来の姿への回帰である。

以上、本書に述べられている家族論をかなり独断的に要約して紹介した。家族の多様化とか、家族パ ラダイムの転換だとか、家族の個人化だとかいう議論が盛んな家族社会学の現状を考えるとき、本書が 投げ掛ける問題は、かなり重いものがある。細かな内容や論理の展開には、必ずしも疑問なしとはいえ ないが、全体として本書に展開された家族論は、もう一度人間にとっての家族とは何か、という問題を 根本から考えてみる必要性を痛感させられる。そして、何よりも著者の家族への熱き思い、人間への愛 着と信頼への深さ、強さに感銘を覚えずにはいられなかった。

(1998, ISBN4-7606-0318-2，3,500円)

(もちづき たかし·大正大学) 